$$
\begin{aligned}
& 13371 \\
& 564
\end{aligned}
$$



SB 371

.564

Copy 1

FARIMERS' BULLETIN No. 33.

\title{
PEACH GROWING FOR MARKET.
}

BY

\author{
FRTVIN F. SMITH,
}

Division (1: Vegetable, Physiology ani) Pathology.

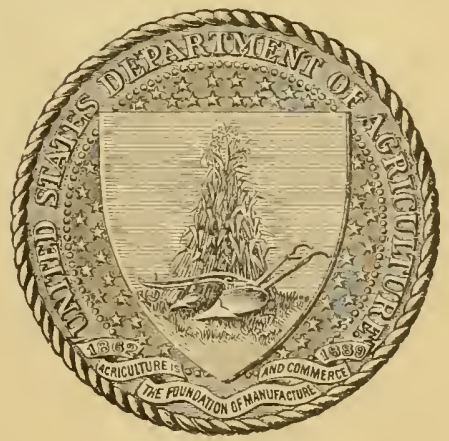

IVASHINGTON :

GOVERNMENT PRINTING OFFICE.

I 895 . 


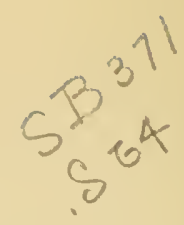

\section{LETTER OF TRANSMITTAL。}

\section{U. S. Departuent of Agriculture,

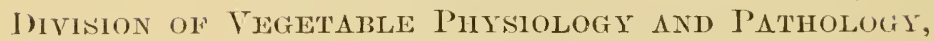 Washington, I). C., August 1, 1895.}

Sin: I have the honot: Farmer's' Bulletin an aiticle on Peach Growing for Market, by Mr. Erwin T. Smith. Dr. Sunith has devoted special attention to the diseases of the peach, and the material which forms the basis of this bulletin has been eollected by him in the conrse of his investigations.

liespectfully,

Hou. J. STERLING MORTON,

$$
\begin{aligned}
& \text { B. T. Gallowas, } \\
& \text { Chief of Division. }
\end{aligned}
$$

2

Secretury.

IN EXCHANGT

F. w. pulnam 


\section{CON T E N T S.}

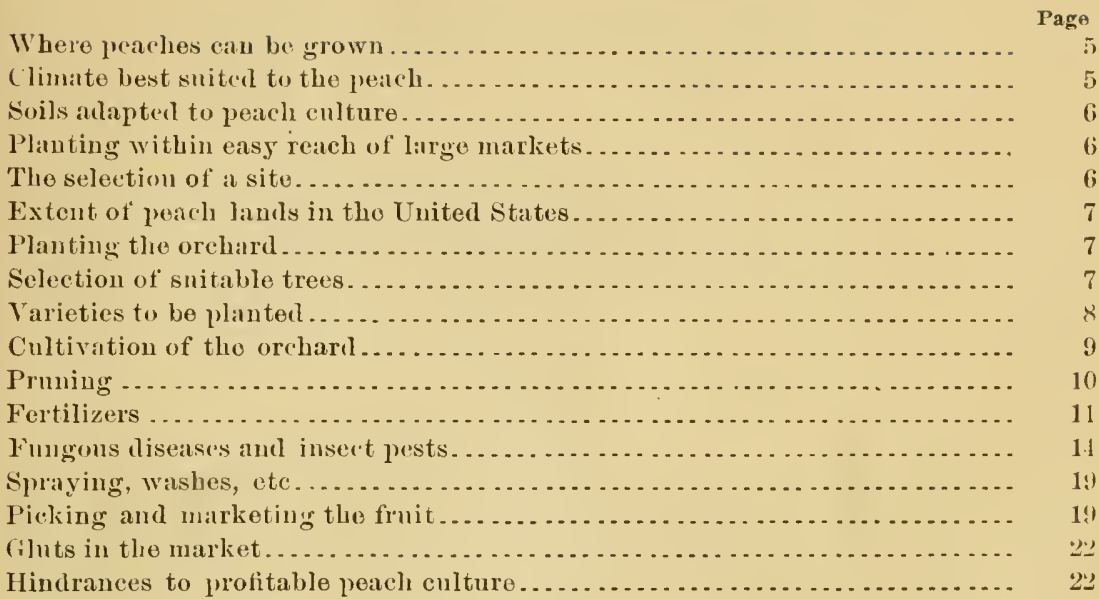

\section{L L USTRA T I 0 N S.}

Fli. 1. l'each tree in a Marylaul orchard showing customary way of prun-

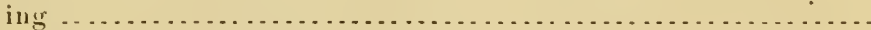

2. Peach tree in a Delaware orchard showing customary way of pruning.

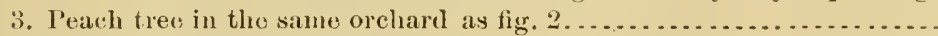

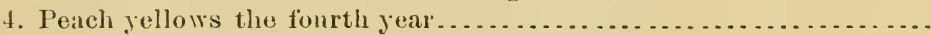

5. Peach rosetto .............................................

6. Heach mildew (Spharotheca pannosa?) on stem and fruit...........

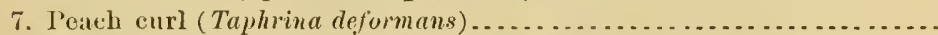

8. Black spot of tho pearh (ciladosporium carpophilum) ..............

9. Root knots due to nenratodes . . . . . . . . . . . . . . . . . . . . . . . . .

10. Tho peat the borer (Sannina exitiosu) . . . . . . . . . . . . . . . . . . .

11. Larva of the pin borer (Scolytus ruyulosus) ....................

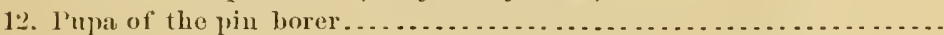

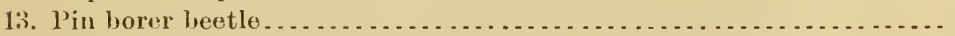

14. linanch of peach showing perforations of the pin horer............

15. Denuded branch showing breeding chambers, larva channels, and pupa chambers of the pin borer............................

16. Black peach aphis (Aphis persice-niger), the common wingless, vivipalrous form . . . . . . . . . . . . . . . . . . . . . . . . . . . . . . . .

17. Black peach aphis (Aphis persica-niger), viviparous, wingerl form....

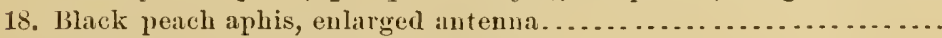

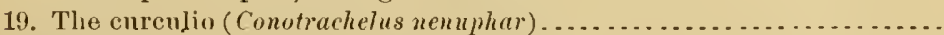

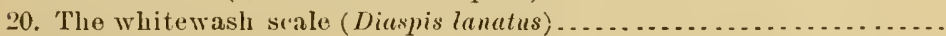

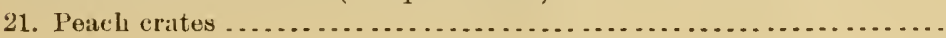





\section{PEACH GROWING FOR MARKET.}

This bulletin is intended for the man who contemplates peaeh enlture rather than for the one who is suecessfully raising this crop. The latter needs no advice, but is rather in a condition to give it, and if he who thinks of planting an orchard ean find a suceessfnl grower by all means let him seek that man's counsel.

\section{WHERE PEACHES CAN BE GROWN.}

In what part of the Uniter States can peaches be grown, is one of the first questions likely to be asked by a foreigner or a person unacquainted with the subject. This question admits of two answers. If peaches are clesired simply for fimily use the answer is that they ean be grown in nearly every State in the Union and in almost any part of any State, eare of course being taken to select the right kind of site, to plant varieties adapited to the climate, and to give suitable winter protection in the extreme North and in ligh mountain regions. Even in the inhospitable climates along our northern border peaches may be grown ont of dloors with considerable suecess if the trees are dug under, tipped over, and eovered with straw each antumn, and not uncovered and righted up until danger from late spring frosts has passed. Some of the finest peaches the writer has ever seen were grown in this way at the Kansas State Experiment Station following a winter and spring which destroyed every blossom on muproteeted trees for miles aromud. The growing of peaches in large orchards for commercial purposes is quite another matter, aud what follows will relate especially to such orehards.

\section{CLIMATE BEST SUITED TO THF PEACH.}

Climate is one of the first considerations in the selection of a place for the planting of commercial peach orchards, and the wide variety we have in the United States affords every opportnmity for selecting a suitable location. The old notion that the peach is a tropieal tree and must liave a warm climate is not well founded. It is a tree of middle latitudes and does not like extreme cold nor extreme heat. The climate of China, which is probably its native home, is in many respects like parts of our own eountry.

Commereial orchards should not be planted in regions much subject to severe winters or to late spring frosts. It is well also to avoid 
regions where the winters are very mild, such as the extreme southern parts of the Tnited States, owing to the fact that the blossoms are apt to be forced out in late winter or early spring and afterwards injured by frosts. It is best to select a climate which is not given to violent extremes of any sort and which has a considerable rainfall, fairly well distributed thronghout the year. Thirty-six to fifty inches of rainfall anumally is abont the proper amount. If the quantity of water precipitated is much below this the deficieney should be made up by irrigation.

\section{SOILS ADAPTED TO PEACH CULTURE.}

There are many kinds of soil in which orchards can be grown suecessfully. At present there are commercial orehards in New England on stomy aud gravelly soils of poor eharacter; in Maryland, Delaware, and New Jersey, on fertile loams aud on very light pine sauds; in l'ennsylvauia, on momntain soils derived from limestones and sandstones; in South Carolina and (ieorgia, on light pine sands and on stiff red clay lands derivel from the local decomposition of granites; in Michigau, on rather heary clay hills, and also very suceessfilly on loans and light pine sands, even on beach sand so light as to be blown abont by the winds; in northwestern New York, on quite a variety of clays, gravels, and sands, forming the old lake bottom of Lake Ontario; in Florida, on flat pine sands; in Kansas, ou deep black prairie soils. On all of these. soils there are $n 0 \mathrm{w}$ growing very successfin and profitable peach orchards.

In general it may be said that the peach prefers light, warm, welldrained, sandy or loamy land with a clay subsoil, although some very successful orchards have been grown mpon rather heavy clays and many on deep sands. Muck soils, heavy clays retentive of moisture, and in general all wet lauds and flat, frosty lands are especially to be avoided.

\section{PLANTING WITHIN EAST REACH OF LARGE MARKETS.}

In the planting of eommercial orchards proximity to large markets and ease of shipment should nerer be forgotten. An exrellent location may be worthless owing to lack of facilities for transportation. There are thousands of acres of land in the United States suitable for peach growing which it would be folly to plant at present owing to lack of shipping facilities. Competing railway and steamboat lines are a great advantage in securing low freights. One of the great drawbacks to surcessful peach growing in the Soutl until recently, and one which still exists in many parts, has been due to the fact that the growers are not able to secure favorable freight rates.

\section{THE SELEC'TION OF A SITE.}

In selecting a site for the orchard several things should be borne in mind. Some fields on a farm may be much better adapted to the peach than others. In general the higher lands ane to be selected rather than the lower, and in northern regions a water front is preferable to an 
inland location; in inland regions a hillside with a northern exposure is generally bettel than one with a southern exposure, this being due to the fact that the northern exposure will somewhat retard the opening of the blossoms, and in this way orehards will escape late spring firosts, while if set in more sumny situations they might be induced to open blossoms a week or two earlier and then be canght by late frosts. In the Michigan peach orchards bordering on Lake Michigan it has been fonnd that the cold air from the lake retarls the opening of the blossom a week or ten days, the inland orehards being in full blossom before those on the lake front have opened. The advantage of this in case of late frosts is obvious.

\section{EXTENT OF PEACH LANDS IN THE UNITED STA'TES.}

The fear has sometimes been expressed that the ravages of yellows and other diseases would finally put an end to peach growing in the United States, but there is certainly no immediate danger. In North Carolina, Sontlı Carolina, Tennessee, Georgia, Missomri, Arkansas, Texas, and California there are many adminable locations for peach growing as yet unocenpied. California alone eonld grow enongh peaches to supply the whole United States.

\section{PLANTING THE ORCHARD.}

Having decided on climate, soil, site, and location with reference to market, tre next thing is the preparation of the land for planting. This should be plowed and cultivated as carefully as for a crop of wheat, eorn, or cotton. The land should then be cross-marked aud holes $d u g$ for the trees at the intersections. In general it is best to plant trees not eloser together than 20 by 20 feet, especially if the soil is in good condition. In some places, however, where the soil is poor and where the orchards are not expeeted to last more than a dozen years, the trees may be planted eloser-for example, 10 feet one way by 20 feet the other. At the time of planting a map of the orchard showing the location of each variety should be made for future use. The neglect of this frequently causes nuch inconvenience. The preparation of the soil, the digging of the holes for the trees, and all necessary work in connection with the planting should be done in advance, so that when the trees are received there need be no delay and consequent dryiug of the roots before planting. If it is absolutely necessary to utilize flat land retaining moisture, furrows should be turned toward the center of 20 foot lands for several years in snceession and the trees fiually planted on the middle portion of these artificial ridges.

SELECTION OF SUITABLE TREES.

The seleetion of the trees themselves is a matter of great importance. It is not necessary that they should be very large, but the trunks should be smooth and well grown and the roots abundant and as 
little injured as possible. To seenre these rlesirable qualities it is rell iu ordering trees to lave a written agreement tonching the points in question, so that inferior trees may be rejected. The roots should not be close pruned except for the removal of mangled or splintered portions, and the holes in which they are set shonld be of such dimensions that it will not be necessary to twist and eramp them in planting. Care should be taken that they are not set shallow-that is, on top of the earth-nor buried mueh deeper than they stood in the original nursery. They should not be set into hard earth, nor shonld the holes be filled with stones and rubbish, but with mellow earth well tramped down. Experience in the United States has shown pretty clearly that peach trees in open orchards do best on peach roots, but if the situation is low and the soil rather heary plum roots ${ }^{1}$ may be substituted, in which latter case the trees should then be closer together, say 15 by 15 or 1.5 by 12 feet. In the United States peaches are not grown to any extent on espaliers or in houses.

Judgment differs as to whether it is best to set June-budded or Angust-budded trees. Generally it will be found convenient to buy the trees of some reliable unrseryman, and such are usually propagated firom buds set in Angust, but if the planter prefer's to grow lis own trees and time is a matter of consequence the seedlings should be budded in June so as to obtain a grafted top the same year.

In the selection of trees special attention should be paid to secure those which are free from fungi and injurions inseets. The greatest care shonld be taken that the trees are not infested by borers, seale insects, or root aphides. Unfortmately trees of this character are sometimes sent ont, and orchards planted from them are sure to give tronble. In general it is best to avoid trees grown in regions much subjeet to peach yellows and peach rosette. In buying trees the planter will do well to deal only with nurserymen who have by lionest dealing gained a well-merited reputation. It is better to pay two prices for trees of an assured character than to take as a gift trees from doubtfin sonrces.

VARIETIES TO BE PLANTED.

The selection of varieties is a matter of considerable importance, and 110 general rule applicable to the whole United States can be laid down. Many choice peaches do well only in restricted localities. Some are liable to be winterkilled or to be canght in bloom by late frosts; some are mneertain bearers; some mildew and other's rot badly; some are too tender for loug shipment by rail; some ripen at the same time as better sorts, which are to be preferred; some, like the Elberta, have many good qualities but fall short of the finest flavor. A variety for commercial purposes must combine as many good points as pissible. The tree must be hardy and productive; the fruit must be of good size,

\footnotetext{
'In selecting plun stocks care should he nserl to secure a variety which makes a good and lasting union. The Marianna should not be used for a stock.
} 
fine color, and superior flavor, and must be firm enough to stand shipment. The grower who contemplates setting an orchard for profit will do well to stick elosely to the old and well-tried sorts. If he is planting for home use or pleasure, then he may seleet a wider range of varieties, including all the choicer sorts, irrespective of other consirlerations. The man who is in the business to make money can well afford to let his neighbor try all the new sorts. The remarks which follow on the selection of varieties apply especially to the eastern United States, and with the limititions alrealy expressed.

For market orehards the following have been found the most generally profitable varieties: Alexander, Amsten, Troth, Rivers, Lonise, Hale, St. John, Mountain Rose, Crawford Early, Foster, Old Mixon, Stump, Elberta, Crawford Late, Reeves, Wager, Fox Seedling, and Beer's Smock. These varieties ripen in about the order named. Owing to special conditions which prevail in the extreme North and at the far South some of these varieties would not be successful. For instance, in Michigan it has been found that Crawford Early is very likely to be winterkilled or canght in blossom by late spring frosts, and a number of other hardier varieties-for example, Barnard and Snows Orangehave been substituted for it. The same is true in Comnecticut, where many of the old varieties are liable to be caught by late spring frosts and where the Crosby has proved exceptionally hardy. On the other hand, in Florida many of our choice sorts are nearly worthless owing to the earliness with which they bloom. There and in Texas the socalled Chinese sorts-Peen-to, Honey, and crosses-have proved more successful. In middle and npper Georgia the Elberta has proved one of the best peaches. Husted's No. 80 is also an excellent peach for that locality, ripening a few days after the Alexander. In general for that region early varieties are to be recommended rather than late sorts, which, however tine, wonld eome into competition with Delaware and New Jersey peaches on a falling market. In the monntains of Maryland certain late varieties not suitable for the lowlands of Delaware and New Jersey have proved exceedingly remunerative, reaching good size and fine color, and coming in late, when the markets are comparatively empty and prices are high. Among these might be mentioned Salway and Bilyeu.

\section{GULTIVATION OF TIIE ORCHARD.}

The orchard subsequent to planting shonld be cultivated as carefully as a field of corn. The practice of successful growers varies a good deal in this particular. Some cultivate the orchard from the start without erops; others plant corn or tomatoes between the trees for the first two or three years-that is, until the orehard comes into bearing. There is no objection to this, provided the soil is strong and well fertilizerl; on the contrary, there appealr to be some advantages. There is a choice, however, in chops that shonld be grown, and on no accont 
should potatoes or wheat be cultivated in orehards. As soon as the

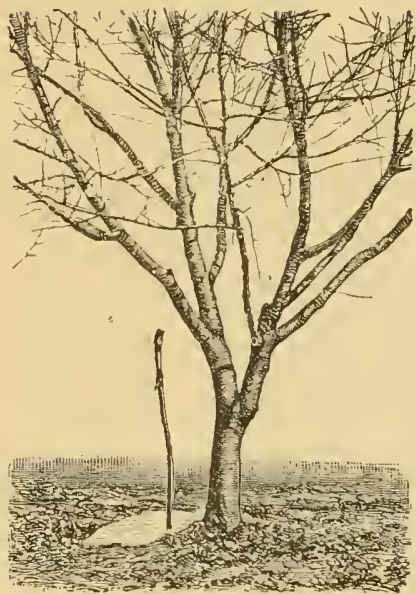

Fic. 1.- T'each tree in a Maryland orchard, sbowing customary way of pruning. Stake alosut : fert high. trees come into bearing un erop of any sort should be grown between them, but each year the orchard should receive a shallow spring plowing and frequent eultivations mutil July. Most of the grow. ers in the middle Eastern states prefer not to cultivate the soil later than this, but in some regions it is the practice to cultivate almost the year round, and even in Delaware very sucressful growers have followed this practice, keeping the soil stirred from early spring until late antumn. As a rule deep plowing shonld be avoided. The peach tree is almost as sensitive to clean cultivation as cotton or tobaceo, and no man can experet to be very sncessful in the enltivation of the peach who allows his trees to stand in sod or fatils to give them elean tillage during at least a part of the season.

\section{PRINING.}

Opinions differ as to the proper methor of pruning. When the trees are planted they shomld be cut back to within 1 or 2 feet of the ground, the entire branched top being removed. The remainingluds will push vigorously. and three or four of these should be se. lecterl to form the new top, eare being taken that they come ont from different sides of the stem and not too elose together, but at a distance of several inches mp and down the trunk. When the branches from these buds have grown to be several inches in diameter they shonld support a spreading or vaseshaped top (figs. 1, 2, 3). The proper starting of the new top is a matter of some importince, for if all of the branches have been allowed to grow ont from nearly the same point on the trunk, when the tree has matured the giving way of a single limb under weight of fruit or stress of wind is very apt to involve all the rest and split the trunk

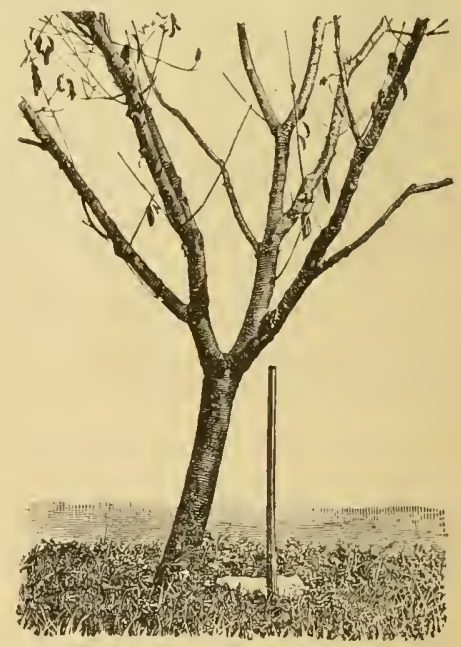

FIG. 2,-Peach tree in a Delaware orehard, showing customary way of pruning. Stake about 3 f'eet high. from top to bottom. Such mishaps "an he readily avoided by starting the main branches at different heishts. 
For orchards on most of the peach lands of the Eastern States comparatively little pruning appears to be necessary. Some growers pracetice "shortening in" annmally orer the whole top, but in general this is not desirable. However, if the tree has made an execelingly vigorous growth it can be practices to good advantage, and is generally hest done in early spring. The aim in pruning should be to get a tree fiee from dead wood and full nearly to the main trunk of sulall branches capable of bearing fruit. Care should be taken in pruning to aroid entting away bearing branches from the base of the limbs, for by this method long, strag. gling bramehes, having fruit-bearing limbs at the top only, are often pro duced. Some growers prome the trees

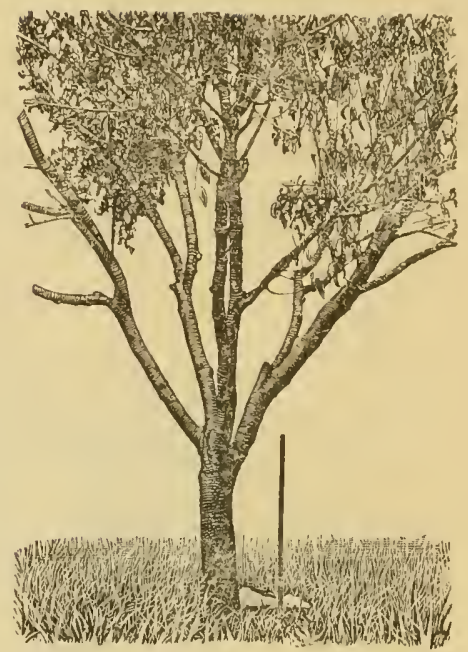

Fiti.3.-Peach tree in the same (wehard as bì. 2.

so that the main trunk shall be 4 or $\delta$ feet high, but in general this is

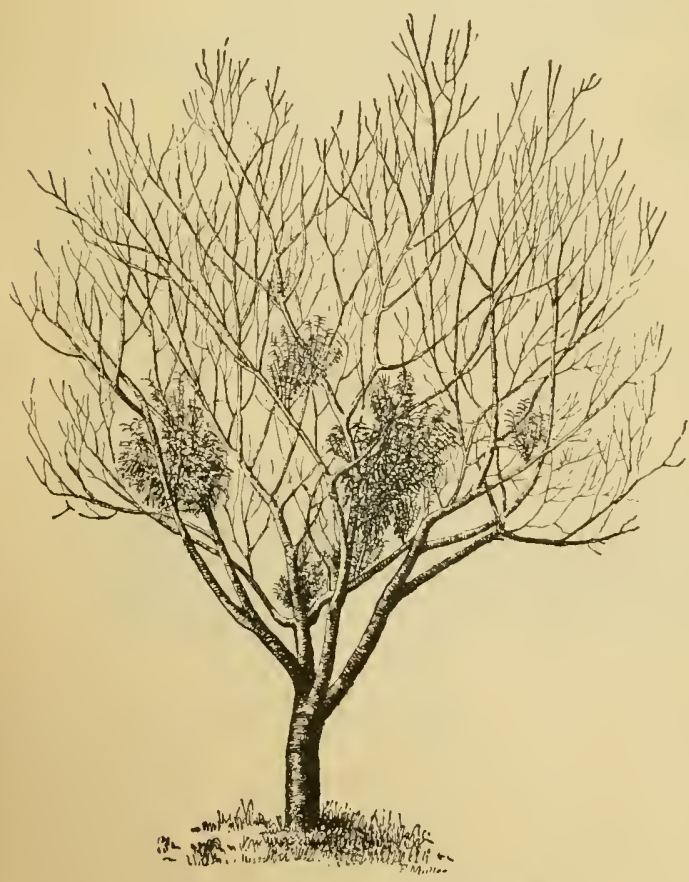

Fia. 4.-Peach yellows the fourth year. not to be recommenderl. It is much better to make them branch low in vase form. The only advantage of the other method is greater ease in cultivating close to the tree, and it has on the whole disadvantages whith more than comiterbalance, one of which is the greater exposure of the trunk to hot sums and another the increased danger of injuring the bark of the trumk by plows and cultivators.

\section{FERTILIZERハ.}

Some words are neces sary on the use and mis. use of fertilizers. Unless the trees are on stroug land it will be neressary as som as they eome into bearing, and yearly thereafter, to give them 
each spring or antumu some speeial fertilizer. There can be no objection to the use of well-composted harnyard manure. Where this is not procurable dependence must be jut on clover and commereial fertilizers, taking eare always that the latter are obtained from reliable sources. In general the dependence should be on potash salts and phosphates rather than on nitrogenons fertilizers. The peach can be injured readily by excess of nitrogen. Its effect upon the trees is to prodnee an excessive growth of woor and foliage at the expense of

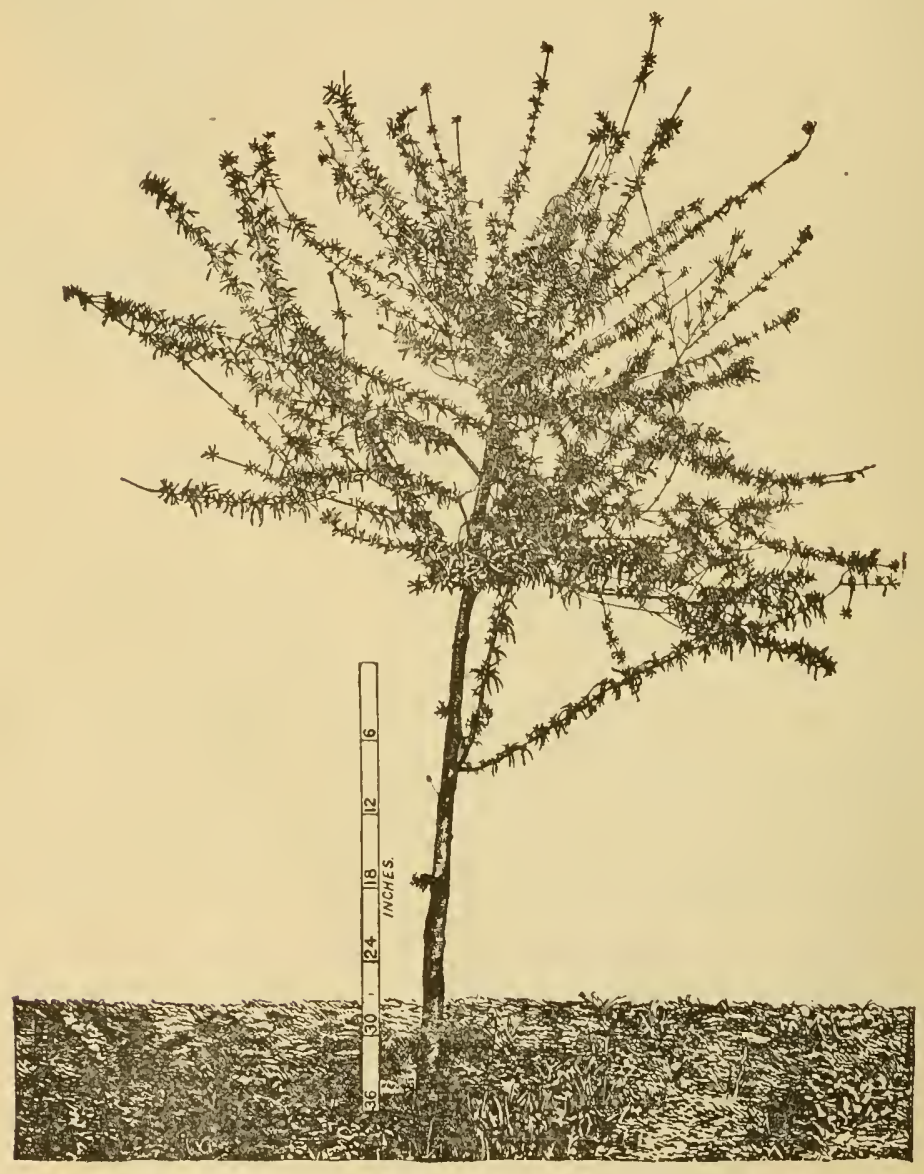

Fig. 5.-Peach rosette. A budded tree attacked in spring and photographed in June.

the fruit. Fifty to a lumbled pounds per acre of nitrate of soda or its equivalent in dried blood or sulphate of ammonia is usully as much nitrogenous fertilizer as any orchard requires and many orehards do not need it at all. Muriate of potash, kainit, or sulphate of potash may be used in large quantities without injury. Fonr to five hundred pounds per acre will do no harm, provided it is not put too elose to the truuks of the trees. 
The same remarks apply to dissolved rock phosphates and to bone stperphosphates and varions bone mixtures. They have been applied in large quantities, even as high as a thousand pounds per acre, without injury; generally lesser quantities will suffice. Potash salts and phosphates should be put on and plowed down in the antımm and nitrogenons fertilizers alway's in the spring. Usually the effects of the latter disappear the same season. Where the grower has opportunity to procure $\mathrm{nl}$ leached hardwook ashes these also may be used, and can be applied in large qnantities without injury. A good home made fertilizer ean be prepared by composting broken or coarsely ground bones with unleached hardwood ashes until the bones become soft. The grower who has not tried the effeets of regularly fertilizing bearing orehards will be surprised at the difference in sumntity and quality of the fruit which will result from careful fertilization. Judicions fertilization will bring large returns in the way of fine crops and

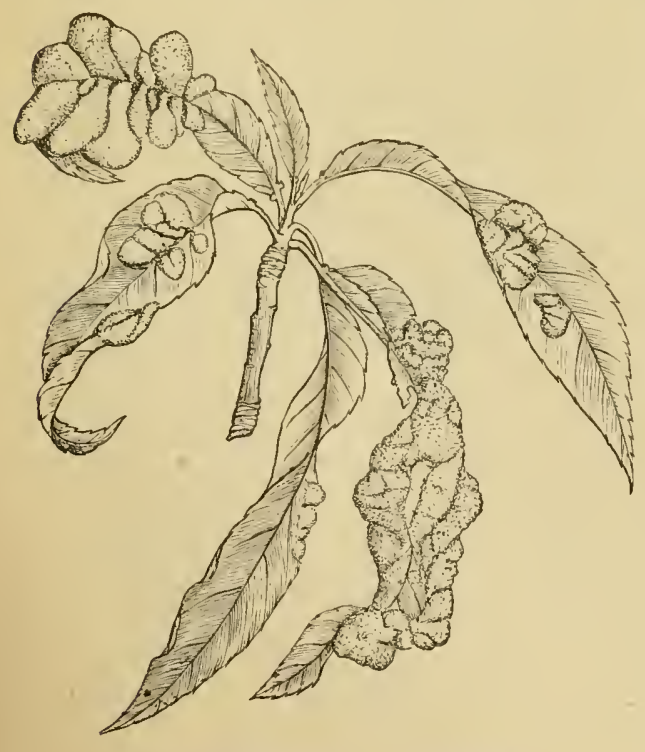

Fig. 7.-Peach cur! (Taphrina deformans).

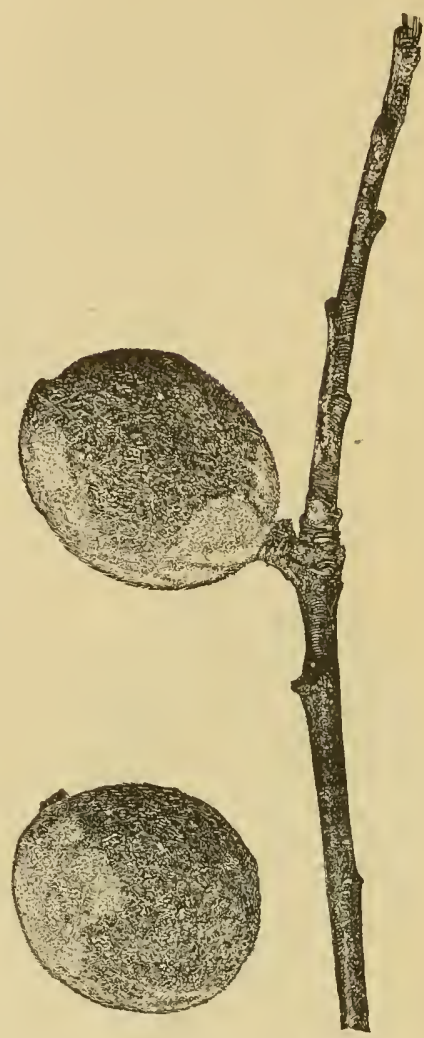

Fig. 6.-Peach mildew (spherotheca pannosa?) on stem and fruit.

good prices. Even the most barren looking yellow sands withont elay subsoils ean be made to produce enormous crops of luscious fruit year after year by proper attention to cultivation and fertilization. Where it is impossible to procure fertilizers the grower must depend on prolonged cultivation of the soil and the oceasional growth in the orehard of green erops for plowing un.

der, e g., cowpeas, crimson clover, ete. Much can be done in the way of furnishing an orchard food by repeated stirrings of the soil. 
The peach tree is subject to various diseases, and no one should venture upon peach growing in a commereial way without having a reasonably good nuderstanding of what the difficulties are in this direction. Peach yellows (fig. 4) and peach rosette (fig. 5) are two of the most destructive diseases. No remedy is yet known for either, but experi ence seems to show (learly that yellows may be held in check by the destruction of affected trees as som as they appear, provided all the growers of a community unite in praeticing it. In planting an orehard the grower will of course, if possible, select a region free or nearly free from such diseases. These diseases attack all varieties. Mildew (fig. 6), on the contrary, is a fungous disease which appears to be restricted principally to certain sorts-the serrate-leaved varieties. It is serionsly troublesome only on the Pacific Coast. In the Lastern States the only remedy yet known is to pull out the affected varieties and plant others. Peach curl (fig. 7)

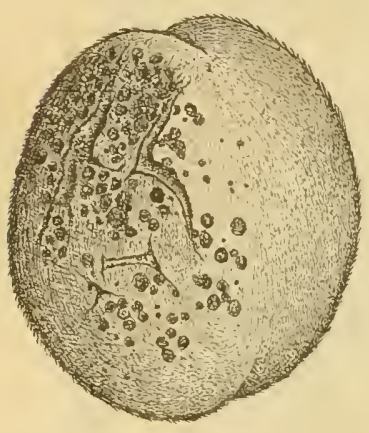

Fig. 8.-Blark spot of the preach (Cludosporem carpophilum). is a clisease distorting the foliage and cansing it to fall in spring. It is widespread and very serious some years; otler years it is but little prevalent. This disease also has been most troublesone in California. It is due to a fungus which may be held in check by spraying, as appears elearly from recent experinents made in California by Newton B. P'ierce, of this division. The peach eercospora las also given some trouble in California. I fungons tronble known as black spot (fig. 8) often leads to eracking of the fruit and subsequent rot, especially in rainy periods. This is most prevalent on late varieties. Rot is one of the most serious troulles that visit the grower. The disease is due to a furgus, and in wet, hot weather it spreads with great rapidity from frnit to tinit, and even attacks the peaches in baskets on the way to market and while on the fruit stands. It is a discase that winters over in the rotterl fruits of the previons year which either remain hanging on the tree or have fallen to the gromul, and is to be combated by carefully removing and burning all affected fruit. If this is not done systematically the crop may be destroyed even before it is out of blossom. Spraying with copper fungicides las been recommended for this disease, but as yet the evidenee in their favor is not entirely conclusive. Sulphur dust blown into the trees during the prevalence of the rot has also been recommended and appears to have some value. A safe, efficient powder or spray for the prevention of this disease would be invaluable.

Crown galls or root galls are irregnlar tumors on the trunk and roots. These are often of large size and ocenr most frequently at the 
junction of the root and stem. This disease oceurs in many parts of the United States, in mureries as well as in orehands, and is seriomsly prevalent in parts of New Jersey, Texas, and Califormia. No rem. edy is known, and even the canse is yet to be determined. Many growers think the disease is communicable, and in planting orchards it is safe to reject all trees showing any sigus of it.

The root knot, which should be carefully distinguished from the preceding, is a disease caused by a small "eel worm" or nematode. The linots (fig. 9) dne to this canse are generally much smaller than the preceding, and on microseopic examination of fresh knots it is usually not difficult to find cavities containing the eel worm in various stages of development. This nematode attacks the roots of a great variety of plants and is quite troublesome to the peach in parts of Georgia, Florida, and other Gulf States. The only symptom which the writer las seen above gromnd was scanty growth.
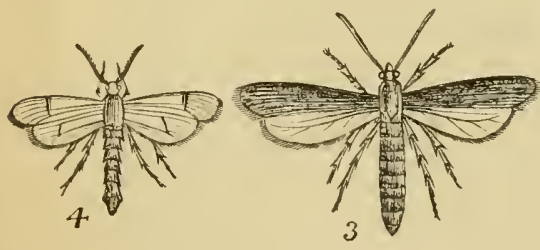

2
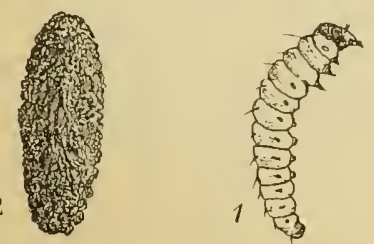

FIG. 10.-The peach tree borer (Sannina exitzoset). (1 and 2, original; 3 and 4, after Riley.)

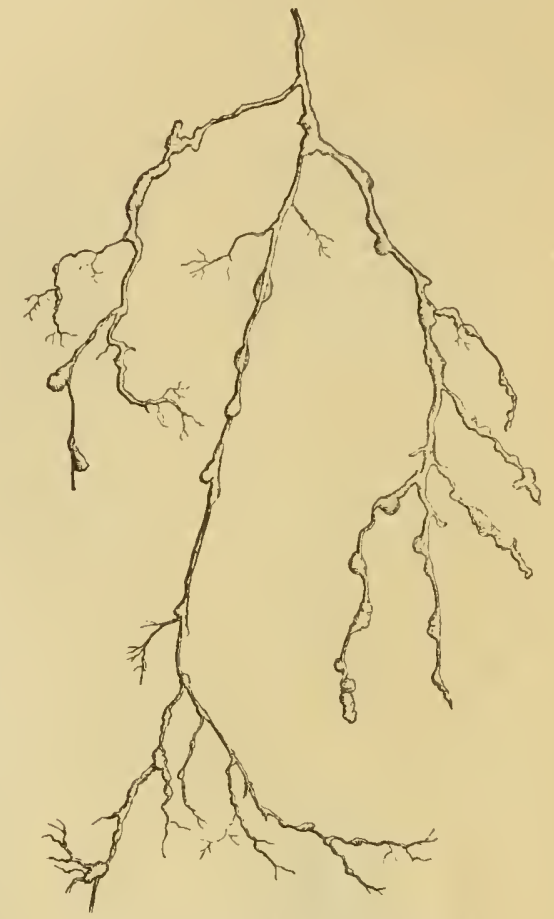

Fig. 9.-Rgot knots due to nematorles.

No guod remedy is known. Of course trees affected with rootknot should never be planted.

Borers (fig. 10) are exceedingly troublesome in some regions, especially on sandy soils. A great number of washes and various labor-saving devices have been recommended, but the best method for dealing with them is the old one of carefully nucovering the trunk of the tree at the earth surface and digging them out with a sharp knife. In sandy lands they should be attended to twiee a year-spring and fall. It is back-aching work, but can scarcely be trusted to an inexpe-

rienced hand, who will often do more injury to the trees than an army of 
borers. Of labor-saving devices one of the best, especially for young trees, is the covering of the base of the trunk in early spring with straw or cheap Chinese matting, the lower end of which should be buried an

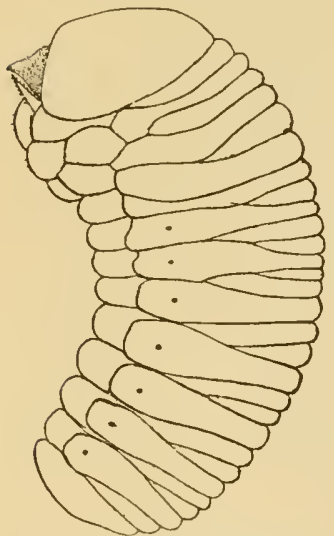

FIG. 11.-Larva of the pin borer (sicolytus rugulosus), enlarged 22 diam. (Forbes.)

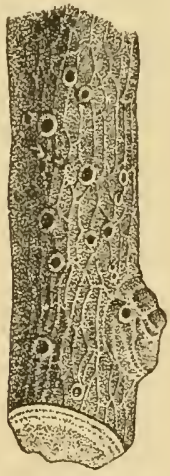

Fig. 14.-Branch of peach, showing perforations of the pin borer, natural size. (Forbes.)

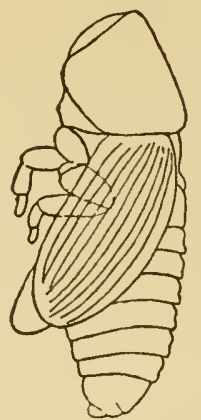

FIG. 12.- P'trpil of the pin borer. Sile view, 20 diam. (Forbes.)

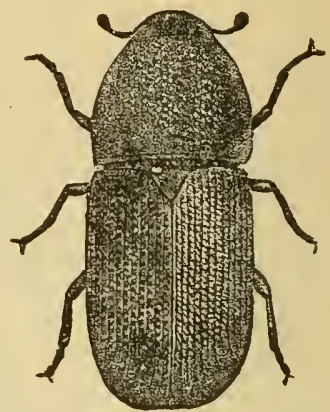

Fur. 13.-l'in borer beetle, 20 diam. (Forbes.)

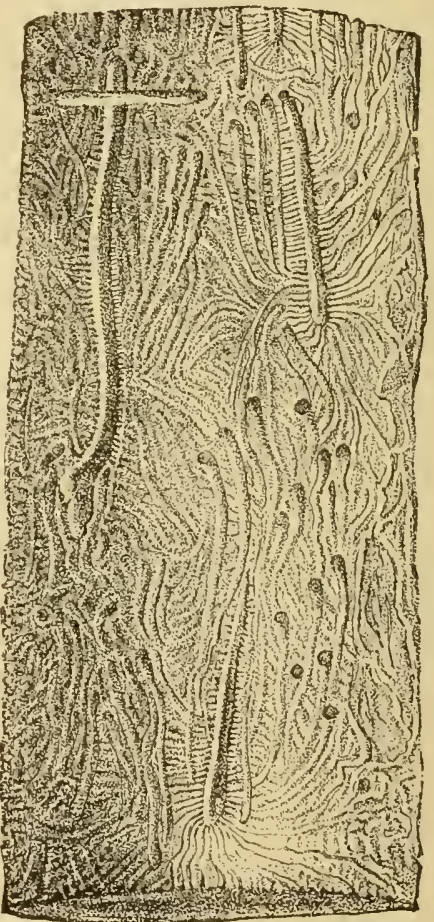

FIG, 15,-Denuded branch showing breeding chambers, larvo channels, and pupa ehambers of the pin borer, natural size. (Forbes.)

inclu or two in the soil. This compels the insect to oviposit on the upper part of the trunk and on the branches, where the larva are easily found and where they do less general and permanent injury. 
The pin borer, a seolytid beetle of Enropean origin (figs. 11, 12, 13, $14,15)$, has in recent years become rather troublesome in the eastern part of the United States. No good remedy is known, but some trouble can be avoided by annully removing all dead wood from the orchard and taking care that it is not piled anywhere in the vicinity. This should be done in the fall or winter. The insects prefer sickly trees, but while the larve are generally confined to such trees, the mature beetle often migrates to healthy trees and feeds upon them, to their great injury, the gummy trunks appearing as if peppered with fine shot. The most serious depredations the writer has seen on healthy trees were where piles of dead wood from old peach orchards were placed near healthy trees. Two eases in particular-one in Maryland and the other in western New York-were very striking, the injuries beginning in trees near large piles

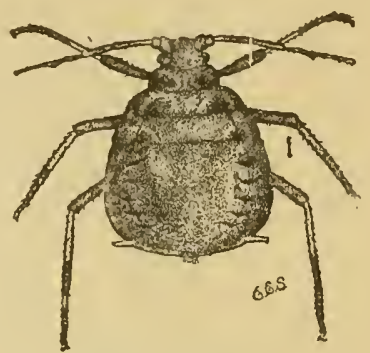

FIf. 16.,-Black peach aphis (Aplis persicceniger), the com mon, wingless, viviparous form (Slingerlaurl.) of dead wood and beeoming less and less in trees more renote from these piles until all traees of injury disappeared.

Brown or black root aphides (figs. $16,17,18$ ) are very eommon in the sandy lands of New Jersey and Delaware, aud also oecur in other parts of the Eastern States. The insect sometimes appears on parts above

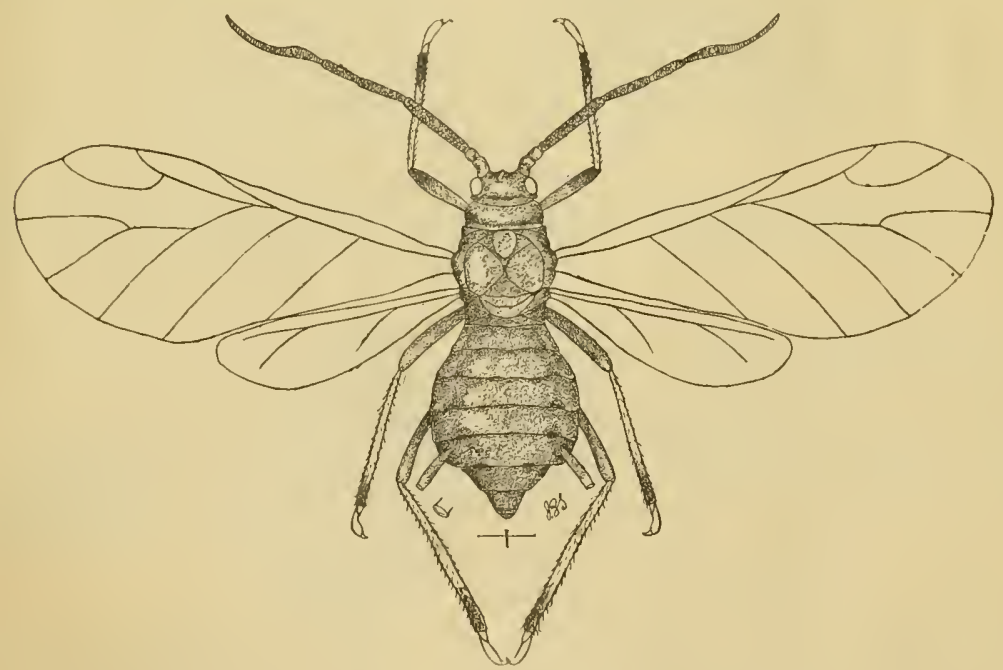

Fra. 17.-Black peacl aphis (A phis persice-niger), viviparous, winged form. (J. B.Smith.)

ground, but the ehief injury is done while it is out of sight. As before stated, care shonld be taken that this inseet is not introduced into the orehard on the roots of the trees when they are planted, and if there? is any reason for thinking that the roots are infesterl the trees should $4806-\mathrm{No} .33-2$ 
either be discarted or else dipped into some insecticide before planting. The underground depredations of this insect stmut the tree so that it dies or makes very little growth for several years.

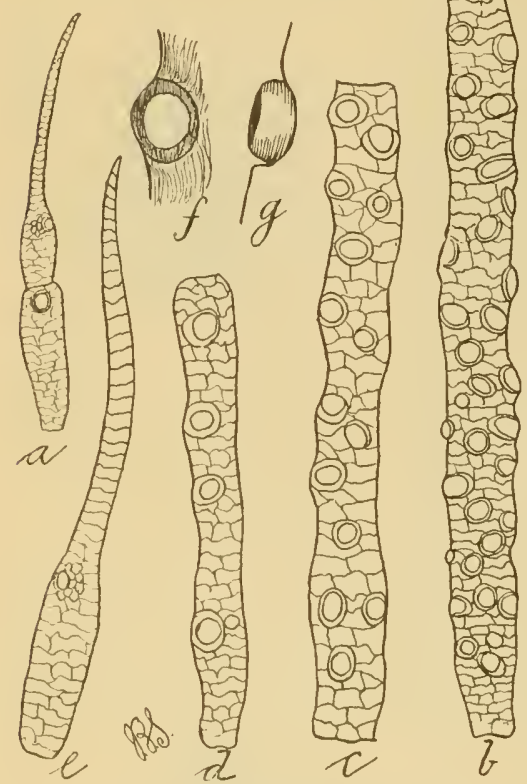

Fic $18,-$ Black peach aphis-joints of antenna: $a$, of young lice; $b$, first loug joint of winged form; $c$, second; $d$, thirl; $e$, whip joint; $f$, top viow; and $g$, side view of a single sonse pore. (J. B. Smith.)

Stunted trees may, however, be startel into a more vigorous growth by lieavy applications of tobaceo dust dug into the earth, and they may sometimes be brought ont and induced to make a good growth by the application of strong stable mamure. The eureulio (fig. 19) is always present, and no safe remeily is known. It can be depended on to take a considerable part of the erop each year, and in years when the yield is scanty it is sometimes content with nothing short of the whole erop. This is especially apt to be the case when spring frosts have mululy thimmed the crop or have restricted it to particular orchards. Arsenical sprays will hold the eurculio in check, but are scarcely to be recommented for the peach, since they are very apt to cause its leaves and fruit
nches. If used at all the greatest to fall and may even kill small branches. If used at all the greatest
care should be exercised. In some cases it miglit pay to capture and destroy the beetles by jarring then onto a framework covered with sheets.

Seale insects lave thus far done but little injury to peach trees in the Eastern States; but the enemy is present, and one species in larticular, recently introdncen from the West Indies (a white seale entirely covering trunk and limbs and quickly killing the tree), is already as far worth as Washington, D. C., and

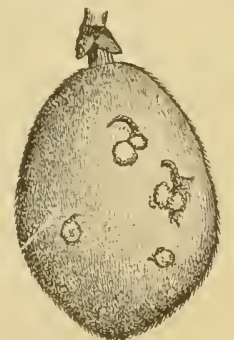

FIG. 19.-The curculio (Conotrackelus nemuphar) 1, Natural size (original); 2, much onlarged (after Howard).

is likely to be very troublesome when more generally distributed. Growers should be on the lookont for this pest (fig. 20) and burn infested trees at sighto 
SPRAYING, WASHES, ETC.

A word abont sprays and tree washes in comection with peach-tree diseases is not out of place. Many have been recommended without proper inquiry as to their merits, and the results of their use have been in some cases so disastrous as to prejulice the whole community agininst any kind of fungicidal or insecticidal treatment. 'Twice the writer has known of fine orchards being ruined by the application to the trunks of washes containing tar, soap, and arsenites. In one case the grower was obliged to remove a whole orchard 7 years old, the trees being either killed by the application or injured beyond recovery.

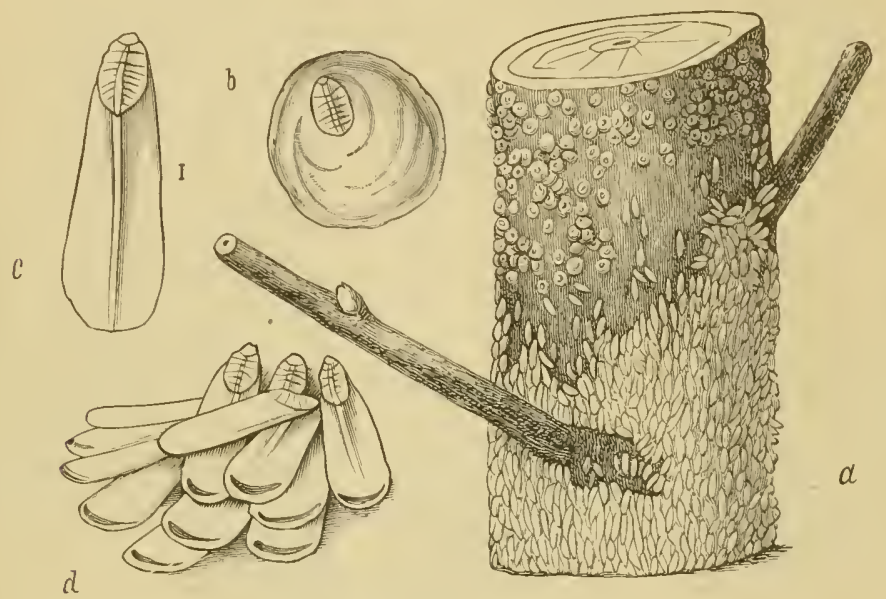

Fir. 20.-The whitewash seale (Diaspis lanatus). $a$, section of peach trumk with male and fernale sealegy in situ, matural size; $b$, seale ol alult female; $c$, lo. male; $d$, do. iu natural positrou, eularged (II)warel.)

Spraying the foliage for insect and fungous diseases must also be fol. lowed with unusual caution. The leaves of the peach tree are very sensitive to acids and to arsenical poisons. However, peach trees may be sprayed with Bordeanx mixture without dauger, provided proper care be taken in its preparation. The lime must be freshly slaked and must be in excess.

\section{PICKING AND ILARKETING THF FRUIT.}

The first crop of fruit is always a matter of special interest, and the inexperienced grower is likely to allow the trees to overbear if not specially cautioned. After the June drop has passed, if the trees are heavily laden a very considerable number of the peaches shonld be pulled off. It takes much less labor to pick them at this time than when they are ripe, and the remaining fruit will be enough larger and better in flavor and color to more than compensate for this thinning. 
Thinuing is not very generally practiced by peach growers in the United States, but if judiciously done no work in the orchard will give better returns. Some of the qualities especially desirable in a crop of peaches are size, flavor, and color. These desirable points ean not be expeeted when the tree is allowed to overbear, in which event the fruit is likely to be small and green and inferior in eolor, and will bring a correspondingly poor price when put mon the market. The extra labor involved in handling a large erop of inferior fruit is also a matter not to be forgotten. Some years thimning will not be necessary, but in years when the trees are burdened with fruit it shonld not be omitted.

Picking and paeking are matters which require the personal attention of the grower. These can not be trusted to hired labor without striet oversigut. The peach slould be picked and packed as earefully as an orange; should never be poured from basket to basket; should never be bruised in handling; should be carefully assorted by grades; and should be putup for market with an eye to attractiveness, so that the best prices may be obtained. It is not strictly proper, lowever, to put red netting over green fruit. There is just the right time to pick for market, and this is something to be learned by experience-a day too early and the peaches are green, a day too late and they are overripe and will be soft and bruised and unsilable before they reach the consumer. No fiuit requires greater experiition and better judgment in picking and marketing, and in these partienlars the peaeh is strikingly in contrast with the orange, which never worries the grower, but may be picked and marketed any time from November to April, barring aceidents from unexpeeted frosts.

In general peach growers in the Eastern States are very carelessalmost indifferent-as to the manner of shipping fruit to market, and the result is that such fruit, while often of a very superon quality, rarely brings as good prices as inferior fruit put up with speelal pains to make it attraetive. The baskets in general use in the Eastern States are too large for retail trade. Grower's of peaehes on a large seale in New Jersey, Delaware, and Maryland seem to think that they ean not handle their vast quantities of fruit in small baskets. Growers in Miehigan and Califormia ${ }^{1}$ have learned better and send their fruit out in much more attractive form, the result being that they get better prices. Florida fruit also comes to market in good shape, and the Florida crate is one of the best. 'The ehoicest grades of peaches should never be sent to market in large baskets, but each fruit should be wrapped separately and sent with as much care as eggs if the best prices are desired. For the canning house and the wholesale trade the Delaware

1The California crate brings the fruit safely in car load lots as far as Chicago, but from this point eastward, in the hands of express companies, sometimes as much as 20 per cent of the peaches are bruised so as to be unsalable owing to the thin sides of the crate. These packages should be made of thicker material or else should have a partition through the middle. 
basket is undonbtedly one of the most eonvenient forms for shipment. Inferior fruit shond be kept at home and dried or fed to the pigs. The unprofitable handling of a large part of such fruit might be avoided by thinning, as alrearly suggested.

On some accounts it is highly desirable that the fruit shonld be transported by water if the distance is not great and the journey can be made rapidly, otherwise it must go in cars and the extra jar must be compensated for by rapid delivery and sale. Of course when peaches are shipped long distances in warm weather particular pains must be taken to see that the ears are properly iced and that there are nodelays in transit, and when they come from the Pacific Coast they must neces-

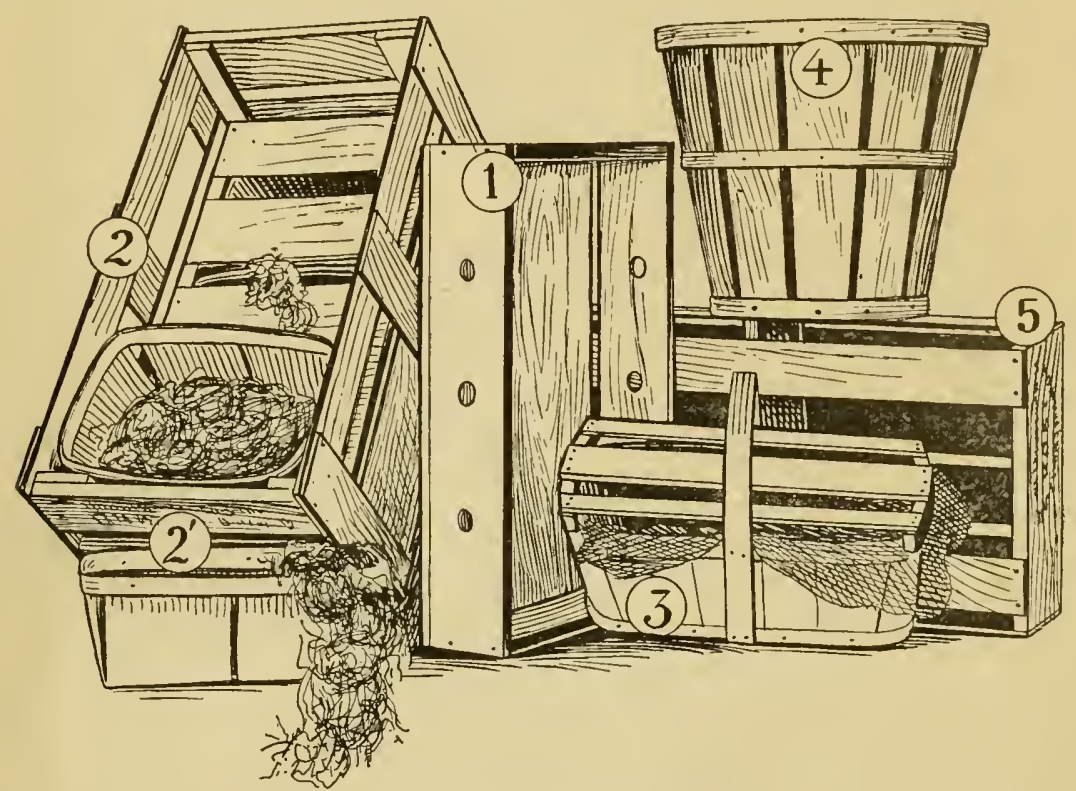

Fic. 21.-Peach crates. 1, California; 2, Florida; 2', single basket from same; 3, Michigan; 4, Dela. ware; 5, North Carolina.

sarily be pieked green. Eastern growers have an advantage over those on the Pacific Coast in the much finer (quality of fruit grown and in being near to market, so that their peaches may be allowed to ripen on the tree, something very necessary to the full perfection of this fruit; but these great advantages are largely lost by carelessness in packing and shipping, and consequently the California peach growers are generally able to command a better price in New York markets than Eastteru growers. Mention has already been made of the desirability of planting orchards where competition in transportation exists. This aftords to growers of the choicest fruit a reasonable guaranty that the whole of their profit will not be swallowed up by exorbitant freight rates. 


\section{GLUTS IN THE MARKET.}

In years of great abundance another serious cause of loss is dne to what are known as "slumps" in the market. Most Eastern-grown peaches find their way to a few large markets, where prices necessarily break down when a large quantity of fruit is suddenly throwu npon them. At times when a glnt exists even the lest frnit will scarcely pay for the baskets in which it is shiper, much less for transportation, picking, packing, ete., and this may happen several times during the season. This ruinous state of affairs is not attrilontable to overnodnetion, but to maldistribution. The erying need in the Eastern States is for a system of distribution which will prevent gluts in the market. It is well known that at the very time when these "slumps" oceur in New York and other large centers hundreds of smaller towns in the interior can not procme peaches at any price.

The writer has frequently paid 5 cents apiece for quite ordinary peaches in interior towns in New York and Pennsylvania and fartlee west when the finest peaches cond searcely be given away in New York and Philadelphia. This suggests that much loss could be avoided by a well-organized system of distribution. Just low this shall finally be brought about is a difficult problem to solve, but it is certainly one of the things which peach growers must study to accomplish. It is worth the earnest consideration of pomological associations, boards of agrienture, and all who are interested in growing peaches.

It wonld seem that there might be some arrangement with the local dealers in many of the smaller towns in the Eastem Tnited States and with large dealers in the eities wherely telegraphie advice conld be sent every day during the season to some centrally located place in each peach region and thence communieated to all the growers. In this way it would be known where the market was full and where empty, and shipment conld be arranged accordingly. Cooperation is the keynote of snceess. Indeed, withont hearty cooperation and compact organization little or nothing ean be accomplished, and yet to secure and maintain such organization presents the ehief difficnlty. Home consumption is another way to avoid gluts in the market; also the judicions nse of eanning and drying houses.

\section{HINDRANCES TO PROFITABLE PEACH CULTURE.}

One of the elief difficnlties in the way of successful peach growing is undoubtedly the ignorance of the grower. The man who will not grow choice varieties, prefers seenllings, will not properly thin his frnit, will not properly grade it, will not keep the culls at home, will send to the market when he pleases and where he pleases, and who will not combat insect and fungou: pests, can not make peach culture pronitable, and the ouly thing for him to do is to go ont of the business. 
Many of the serions troubles which beset growers can be measurably orereome by intelligent foresight. The thing which is least within the range of control is the weather; yet, while growers can not entirely aroid the mischief of spring frosts or the results of hot and rainy weather, even these may be guarded against. The judicious seleetion of advintageous orchard sites, and, in special cases, smudges and spray. ings with water will tend to avert the former, while prompt removal of rotting fruit, extra prompt marketing, and particular eare in packing for shipment will_do mueh to remerly the effects of the latter.

In conchusion it may be said that the labor involved in peach growing is great and the discouragements not a few. The proportion of litilures to snecesses is at least as ten to one, and very few indeed are the men who become "peach kings." The man who is not tull of eneryy and does not enjoy seeing the sun rise every day in the year had better venture lis money in some other business.

Not's.- Since the first edition of this Bulletin fruit growing in the Eastern United States has been serionsly threatened, owing to the introduction and spread of the San José seale (Aspilliotus perniciosus). This scale now occurs in inundreds of orchards in the Eastern United States, and has been reported from quite a good many nmrseries. This very general dissemination has been traced principally to two large nursery firms in New Jersey. These firms imported infested trees from California in 1856 or 1887 and sent ont seale-infested stock for a number of years. The scale has been reported from the following States: Massachusetts, New York, Ncw Jersey, Pennsylvania, Delaware, Maryland, Virginia, West Virginia, North Carolina, Georgia, Florida, Alahana, Lonisiana, Missomi, Ohio, Indiana, Illinois, Arizona, New Mexico, California, Oregon, Washingtou, Nevada, and Idaho.

The San José scale is not restrieted to the peach, but attacks a great variety of trees and shrubs, including all our common fruit trees, and is generilly coneeded to be by far the worst scale in the United States, if not in the world. It has serionsly injured many orehards in Cailifornia and has already destroyed quite a number on the $\Lambda$ tlantic Coast. Great care should be exercised in purehasing stock, and no tree from an infesterl loeality should be planted without rigid inspection. Infested trees should be grubbed up and burned as soon as discovered, even if it refjuires the taking out of whole orchards. Peach trees are now so cheap and easily grown that it is scareely worth while to take any risks with uncertain washes aud sprays. For further information consult Bulletin No. 3, N. S., Division of Entomology, United States Department of Agriculture: The Sun José S'cale. By L. O. Howard and C. L. Mirlatt. 
These hulletins ale sent frew of eharge to any aldress "pou application to tilo Secretary of Agricultue, II: shington, 1). C. Only the following are available for Tistrilution :

No. 16. Leguminous Plauts for (imen Manuring and tor Foeding. P1. 24.

No. 18. Forag. l'lants for the South. l'le.30.

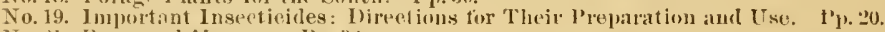

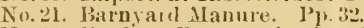

No.22. Feeding Farm Animals. 1'p. 32

No. 23. Fouds: Nutritive Value and Cost. P1. 32.

No. 24. Hog Cholera and swine Plagne. P’r. 16.

No. 25. Peanuts: Culture and Uses. P1. 24.

No. 26. Sweet Potatoes: Cnlture ami Uses. P1. 30.

No. 27. Flax for seed and Fiber. I'p. 16.

No. 28 . Wreeds; and How to Kill Then. P'ls.30.

No. 29. Sonring ol Mt ilk and Other Changes in Milk l'roducts. Pp. 23.

No. 30. Grape Diseast's on the Paeilic Coast. 1'p. 16.

No.31. Altialta, or Lueern. Pp, 23 .

No. 32. Siles and Silage. 1'p. 31 .

No. 33. Jeach Growing for llarket, I'p, 21.

No.34. Meats: Composition and Cooking P'p. 29.

No. 35. Potato Culture. Pp. 23.

No.36. Cotton Seed and Its I'roducts. p'p. 16.

No.37. Katir Corn: Characteristics, Culture, and Usess. 1p. 12.

No.38. Spraying for Frmt Diseases. Pp. 12.

No.39. (Dnion Culture. Pp.31.

No.40. Farm 1)ranage. Pp. 24.

No.41. Fowls: Care and Foerling. I’l. 2..

No. 12. Farts A bout Milk, l'p. 29 .

No. 43. Sewage Disposal on the Farm. P’1.2.2.

No. 44. Commereial Fertilizers. 1'p 24.

No. 45. Some Insects 1njurions to stored Grain. P1. 32.

No. 46. Irrigation in Humid Clinate's. I'p. 27.

No. 47. Inserts Affecting the Cotun Plant. P1.32.

No, 48. The Manuring of Cotton. P'p. 16 .

No. 49. Sheep Feerling. Pp. 24.

No. 50. Sorghum as a Forage Crop. Pp. 24.

No. 51. Stamlard Yarieties of Chickens. P1) 48.

No. 52. The sugar leet. 1'1, 48.

No. 53. 110 w to Grow Mlusliroons. P' 20.

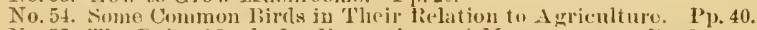

No. 55. The Dairy Herd: Its Formation and Management. l'p. Et.

No. 56. Experinent station Work-I. 1'1.30.

No. 57. Butter Ilikking onl the Farm. 1'1, 15.

No.5s. The Sov Bein as a Forage Crop. Plo. 24.

No.59. Bee Kerping. 1'p. 32.

No. 60. Nethod of 'ining Tobacen. 1'p. 16.

No. 61. Asparagus Culture. l'v. 40 .

No. 62. IIarketing Farm Produce. Pu. 28.

No. 63. Care of Milk on the liarm. Pp. 40.

No. Gt. Duckis auml Geese. Pli. 48.

No. 65. Experiment station Work-II. Pp. 32.

No. vi6. Meadows aum Paslures. 1'p.24.

No. 67. Forestry fur Farmers. Pu. 48.

No. 68. The Black liot of the Cablage. Pp. 22.
No. 69. Eximeriment station Work-ili. IPp.32.

No. 70. The I'rine inal Insect Enemies of the Grape. P'p. 24

No.71. Some kisentials of Beef Prodnetion. Pt).24.

No.72. Cattle Ranges of the Southwest. 1'p. 32.

No. 73. Experiment Station Work-IY. 1'p. 32.

No. 74. Milk as Fouk. I'p. 39.

No. 75. The Grain Simuts. P’o. 20.

No.76. Tomato Growing. Y). 30.

No. 77. The Liming of soils. Py.19.

No.78. Experiment Station Work-V. Ip. 32.

No.79. Experinut Station Work-Vi. P'p. 28

No.80. 'The l'each Twig-borer-an Important Enemy of stone Finats. I'p, I6,

No.81. Corn Cinture in the Sontb. I'p.24.

No. 82. The Culturo of Tobaceo. Pp. P3.

No. 8.3. Tolateco soils. ['1) 23.

No. 8t. Expleriment Station Work-V'11. I'1.32.

No. 85. Fisli as Foul. P'p. 30.

No. 86. Thirty Poisonous Plants. I'p.32.

No.si. Experiment Station Work-TiII. 1'p.:

No. 88. Alkali Lancls. I' 1. 2?3.

No. 81). C'rwpras. l'p. 16.

No.90. 'The At trunfacture ol' Sorghum siruly. I'p. 32.

No.91. P'otalo llistases and 'Their 'Treatment. P'p. 1s.

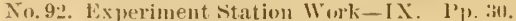

No.93. Sugar as Food. 1'p. 27.

No. 94. Thu Vegrtalle ciarlell. I'v. 24.

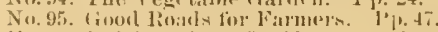

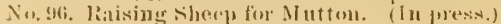



LIBRARY OF CONGRESS

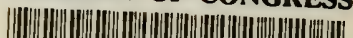

.

00009179343 